\title{
In Memory of Professor Heinrich Lüdin
}

With the death of Prof. Heinrich Lüdin the field of medicine has lost an eminent hematologist and physician, and the University of Basel a distinguished teacher and Chief of the Department of Haematology of the Medical Clinic.

He was born in Basel in 1913 and after completing his medical studies he devoted himself to the area of pathology under the tutelage of Prof. Werthemann and subsequently to that of internal medicine with Rudolf Stähelin and Hans Staub. In the latter field he was promoted to the position of Supervising Physician.

The undersigned first became acquainted with Heinrich Lüdin 30 years ago at a conference of the Swiss Society of Haematology. At this time he already impressed us all as a confident lecturer and authority in his field. With the combination of a clear and concise presentation and his talent for conveying his knowledge, he left a lasting impression.

In Memory of Professor Heinrich Lüdin

\section{7}

Our close friendship began at this time. In 1947 we organised together the first meeting of the 'Société Internationale Européenne d'Hématolo-gie' in Montreux and afterwards we continued working together for many years in this group.

The main interest of Heini' - if I may be so personal - was applied to functional and clinical Haematology. In later years as clinical supervising physician, he still continued to nurture the broad base of medicine. For him haematology was not an end in itself but an integral part of internal medicine and one that should be helpful in diagnosing and determining the patient's illness. Here 1 wish to point out his exceptional didactic talent which, combined with his typical Basel humour, made him one of the best-liked professors among the students and nurses. He was a meticulous and critical researcher. Besides his extensive medical knowledge his patients sensed and appreciated his genuine empathy and concern.

As a physician he was especially interested in the education of nurses and was an active teacher at the nursing school of the Bürgerspital. This led to appointments to various bodies of Nursing Commissions. With the same enthusiasm and dedication he availed himself to military service and was awarded the commission of full colonel and corps physician. He also contributed much to the post-graduate education of our Red Cross officers in the army.

His interest in haematology was, in the beginning, mainly concerned with the examination of living blood cells with the phase microscope. He paid special attention to sideroblasts and siderocytes. Along with these studies he always developed the excellent microscopic photographs himself, the enlargements as well as the slides. Later he turned to serological problems of the haemolytic anaemias.

His habilitational paper 'Organpunktate in der klinischen Medizin', written in 1954, is still worth reading. The same applies to the chapter on the 'Plasmozytom' in the 'Handbuch der Hämatologie'.

In 1951 he took upon himself the additional responsibility of Secretary of Acta Haematologica.

Owing to his questioning mind and his extensive knowledge he contributed much to the success 
of this journal and was appointed Editor-in-Chief of 'Acta Haematologica'. In 1962 he was awarded a teaching position as Professor Extraordinary of Haematology at the University of Basel.

It is common knowledge that especially active and highly gifted individuals avail themselves for the achievement of common goals especially when they possess an excellent talent for organisation. He always found it

368

In Memory of Professor Heinrich Lüdin

most difficult to say no if someone asked him for favour, still in the face of all this work and responsibilities, he remained a very humble person. In spite of the busy working schedule he always found time for his patients, colleagues and friends and most of all for his wife and family. A love for the beauty of nature and classical music were a welcome and soothing relaxation to him.

Suddenly, nine years ago, his untiring efforts and career were interrupted by a massive heart attack. It seems almost miraculous that, thanks to modern and intensive care and the efforts of all his colleagues, he recuperated to such an extent as to allow him to return to his duties at the clinic as supervisor of the Haematological Department.

We all share the sorrow in the loss of a good friend, an outstanding physician and human being as well as an exceptional clinical haematolo-gist. His professional expertise will leave a lasting impression upon the many colleagues and numerous nurses, to whom he was able to transmit a deeper understanding for patients, and above all his outstanding knowledge of internal medicine, specially in the area of clinical haematology.

Sven Moeschlin, Solothurn

The Publishing House and Dr. h.c. Thomas Karger wish to express their appreciation to Prof. Moeschlin for his moving obituary and add that they lose, with the passing of Prof. Lüdin, not only an excellent and highly esteemend editor but also a personal friend. The relationship with Prof. Lüdin spans two generations of the Karger family and we shall keep him in fond memory. S. Karger AG, Basel 